\title{
IMMUNE RESPONSE TO Mycobacterium bovis-AN 5 INFECTION IN GENETICALLY SELECTED MICE (SELECTION IV-A)
}

\author{
CAVALHEIRO J. S. (1), TRINDADE B. C. (2), BALDERRAMAS H. A. (2), \\ HAANWINCKEL M. C. (2), PINTO J. G. G. (2), OLIVEIRA S. L. (2), PAES A. C. (1)
}

(1) Department of Animal Health, School of Veterinary Medicine and Animal Husbandry, São Paulo State University - UNESP, Botucatu, São Paulo State, Brazil;

(2) Botucatu Institute of Biosciences, UNESP, Botucatu, São Paulo State, Brazil.

\begin{abstract}
Mice genetically selected for high $(\mathrm{H})$ and low $(\mathrm{L})$ antibody production (Selection IV-A) were used as murine experimental model. The aim of the present work was to evaluate the macrophagic activity and to characterize the immune response in Mycobacterium bovis- $\mathrm{AN}_{5}$ infected mice ( $3 \times 10^{7}$ bacteria). The response profile previously observed in such strains was not similar to that obtained during $M$. bovis infection; however, it corroborated works carried out using Selection I, which is very similar to Selection IV-A regarding infection by $M$. tuberculosis and Bacillus Calmette-Guérin (BCG). Considering bacterial recovery, $L_{I V-A}$ mice showed higher control of the infectious process in the lungs than in the spleen, whereas $\mathrm{H}_{\mathrm{IV}-\mathrm{A}}$ mice presented more resistance in the spleen. With respect to macrophagic activity, hydrogen peroxide $\left(\mathrm{H}_{2} \mathrm{O}_{2}\right)$ was probably not involved in the infection control since there was an inhibition in the production of this metabolite. Nitric oxide (NO) and TNF- $\alpha$ production seemed to be important in the control of bacterial replication and varied according to the strain, period and organ. Evaluation of the antibody production indicated that the multi-specific effect commonly observed in these strains was not the same in the response to $M$. bovis. Antibody concentrations were higher in $\mathrm{L}_{\mathrm{IV}-\mathrm{A}}$ than in $\mathrm{H}_{\mathrm{IV}-\mathrm{A}}$ mice at the beginning of the infection, being similar afterwards. Such data were compared with delayed-type hypersensitivity (DTH), which was more intense in $\mathrm{H}_{\mathrm{IV}-\mathrm{A}}$ than in $\mathrm{L}_{\mathrm{IV}-\mathrm{A}}$ mice, indicating that antibody production is independent of the capability to trigger DTH reactions and that cellular and humoral responses to $M$. bovis antigens show a polygenic control and an independent quantitative genetic regulation. Differences were observed among organs and metabolites, suggesting that different mechanisms play an important role in this infection in natural heterogeneous populations, indicating that NO, TNF- $\alpha$ and Th1 cytokines are involved in the infection control.
\end{abstract}

KEY WORDS: immune response, Mycobacterium bovis, Biozzi mice.

CONFLICTS OF INTEREST: There is no conflict.

\section{CORRESPONDENCE TO:}

JULIANA SEMIM CAVALHEIRO, Departamento de Microbiologia e Imunologia, Instituto de Biociências de Botucatu, UNESP, 18.618-000, Rubião Júnior, Botucatu, SP, Brasil. Email: jscvet@bol.com.br. 


\section{INTRODUCTION}

Bovine tuberculosis is an infectious disease whose etiological agent is Mycobacterium bovis $(3,5,10,15,20)$. It usually evolves to a progressive stage due to pathogenicity factors related to the cell wall lipidic components $(8,22)$. After phagocytosis, macrophages try to destroy the bacillus but the virulent bacillus can resist or escape destruction (25). Oxygen-reactive radicals released after the contact with the bacillus can kill other bacteria; however, they have little effect on virulent bacilli due to the micosides action $(9,25,28)$.

Cell immunization is the most effective mechanism to control Mycobacterium spp infection. Cell response results in the accumulation of a large number of phagocytes and consequently in the formation of a macroscopic lesion referred as tubercle or tuberculous granuloma (25). A typical tuberculous granuloma is composed of macrophages, multinucleate macrophages, lymphocytes, and epithelioid cells, which are characteristic components of the granulomatous reaction. Granuloma also protects the bacterium from the immune response and is probably responsible for the persistence and latency of the natural infection (18).

In tuberculosis, alveolar macrophage plays the role of a presenter; it decodes the bacillus antigenic components and displays them to the cellular immune system, which is represented by lymphocytes type I, category CD4 ${ }^{+}$.

Despite the inefficiency of the destruction mechanism, the infected macrophage starts to release substances to attract $T$ lymphocytes to the infection site, through the major histocompatibility complex (MHC), class II, at the same time that it displays immunogenic epitopes (proteins and polysaccharides) on its surface. Stimulated T lymphocytes then produce lymphokines, like interferon- $\gamma$ (INF- $\gamma$ ), that enhance macrophage efficiency during enzymatic digestion by releasing $\mathrm{NO}$, a potent antimicrobial agent $(2,12,14,19,21)$.

Since the main defense mechanism against $M$. bovis is linked to macrophage dependence, genetically selected mice (initially developed by Biozzi et al., (4) were used as experimental model in the study and characterization of events observed in the immunological response. This model was obtained by bidirectional genetic selection of mice high $(\mathrm{H})$ and low $(\mathrm{L})$ producer of antibodies against complex natural antigens. The high or low capability to produce antibodies results from the additional effect of alleles located at several independent loci (polygenic control), which are accumulated in $\mathrm{H}$ and $\mathrm{L}$ mice during the selective process. These lines, considered 
homozygote for alleles related to the selective character, represent extreme phenotypes found in heterogeneous natural populations.

Thus, in the present work, Selection IV-A mice were used as an experimental model to evaluate some immune response parameters such as macrophagic activity, antibody production and intensity of hypersensitivity reaction against M. bovis.

\section{MATERIALS AND METHODS}

\section{Mice and Inoculum}

Male $\mathrm{H}$ and L mice (Selection IV-A), 6-8 weeks old, 25g mean weight, were supplied by the Animal Facility of the Department of Microbiology and Immunology, Botucatu Institute of Biosciences, UNESP, Botucatu, São Paulo State, Brazil. Animals of the infected group were inoculated with $M$. bovis- $\mathrm{AN}_{5}$ pathogenic strain. Each animal of such group was intravenously inoculated though the retro-orbital plexus with $0.2 \mathrm{ml}$ of the suspension standardized according to 0.5 McFarland scale, which is equivalent to $3 \times 10^{7}$ bacteria/0.2ml.

\section{Sacrifice}

Animals were sacrificed at days 7, 14, 21, 28, 35 and 42 after infection. On each day, 10 infected ( $5 \mathrm{H}_{\mathrm{IV}-\mathrm{A}}$ and $5 \mathrm{~L}_{\mathrm{IV}-\mathrm{A}}$ mice) and 10 control animals ( $5 \mathrm{H}_{\mathrm{IV}-\mathrm{A}}$ and $5 \mathrm{~L}_{\mathrm{IV} \text {-A }}$ mice) were sacrificed. The procedures adopted were approved by the Ethics Committee for Animal Experimentation of the School of Veterinary Medicine and Animal Husbandry, UNESP, Botucatu, São Paulo State, Brazil.

\section{Recovery of Viable Bacteria}

Recovery of viable bacteria was carried out by plating and counting colony-forming units (CFU) in the spleen, liver and lungs of animals. Fragments of these organs were weighed $(1 \mathrm{mg})$, placed in $1 \mathrm{ml}$ sterile saline solution, and decontaminated with sodium hydroxide adjusted to $\mathrm{pH}$ 6.8-7.6 with $8 \%$ sulfuric acid. Samples $(100 \mu \mathrm{l})$ of this suspension were plated in Petragnani medium in properly sealed plates and incubated at $37^{\circ} \mathrm{C}$ for 60 days.

\section{Peritoneal, Splenic and Pulmonary Macrophages Culture}

The animals abdominal wall was washed with $10 \mathrm{ml}$ buffered saline solution and then massaged; peritoneal liquid was obtained with a hypodermic syringe, placed in glass 
tubes kept in ice bath and centrifuged at 1500rpm for 10min.

Spleen and lung cells were obtained though maceration, washed with $10 \mathrm{ml}$ RPMI medium for cell collection, kept in ice bath and centrifuged.

Peritoneal, splenic and lung cells were resuspended in complete medium for cell culture (RPMI plus 1\% L-glutamine and 10\% fetal bovine serum). A $50 \mu$ l aliquot from this suspension was incubated with $0.45 \mathrm{ml}$ neutral red for $15 \mathrm{~min}$ and macrophages were counted in a Neubauer counting chamber with concentration set to $2 \times 10^{6}$ cells/ml in complete medium for cell culture.

Volumes of $0.1 \mathrm{ml}$ of the suspensions were plated onto each well of a 96-well flatbottom microplate, which was incubated for $2 \mathrm{~h}$ at $37^{\circ} \mathrm{C}$ in $5 \% \mathrm{CO}_{2}$. Non-adherent cells were removed by rinsing the wells with RPMI; adherent cells were again incubated in complete RPMI medium for $24 \mathrm{~h}$ at $37^{\circ} \mathrm{C}$ in $5 \% \mathrm{CO}_{2}$.

\section{Reactive Oxygen Intermediate Production}

Hydrogen peroxide $\left(\mathrm{H}_{2} \mathrm{O}_{2}\right)$ production was determined using the method of Pick and Keisari (24) adapted by Pick and Misel (25). Macrophages were obtained and cultured as described above. After $24 \mathrm{~h}$ incubation, supernatants were removed for NO dosage, and adherent cells were incubated at $37^{\circ} \mathrm{C}$ in a humid, dark chamber; then, reaction was stopped by adding $0.001 \mathrm{ml}$ of $1 \mathrm{~N} \mathrm{NaOH}$. Absorbance was determined using an automatic ELISA microreader, 620nm filter. Results were expressed in nanomoles (nmoles) of $\mathrm{H}_{2} \mathrm{O}_{2} / 3 \times 10^{7}$ bacteria, according to the standard curve for each assay.

\section{Reactive Nitrogen Intermediate Production}

As described above, supernatants from macrophage culture were used to measure NO production through the colorimetric method of Griess (16). One-hundredmicroliter aliquots of supernatants were mixed with an equal volume of Griess reagent containing $0.1 \% \mathrm{n}$-(1-naphthyl)-ethylene diamine diluted in distilled water, and $1 \%$ sulfanilamide diluted in $5 \%$ phosphoric acid. Absorbance was measured in an ELISA microreader, 540nm. Results were expressed as micromolar $(\mu \mathrm{M})$ concentration of $\mathrm{NO}$ released. 


\section{TNF- $\alpha$ Production}

Tumoral murine fibroblast cell line, which is called L929 and is sensitive to TNF- $\alpha$, was used for dosage of this cytokine production. For cytotoxicity assay, $10 \mu \mathrm{g}$ sera from 10 animals previously inoculated were added to each well. One hundred microliters of L929 cells treated with Actinomycin for 3h were also added. After 18h incubation, supernatants were removed, and $100 \mu \mathrm{l}$ of a crystal violet suspension were added for $15 \mathrm{~min}$ to fix and stain cells. Then, the plate was immersed in water to remove stain excess, and $100 \mu \mathrm{l}$ of $1 \%$ sodium lauryl sulfate in distilled water were added to the wells in order to solubilize cells. The optical density of each well was measured in an automatic ELISA spectrophotometer at 490nm. TNF- $\alpha$ production was estimated by using a standard curve (between 40 and $4000 \mathrm{U} / \mathrm{ml}$ ).

\section{Total Antibody Titration}

Ten $\mathrm{H}_{\mathrm{IV}-\mathrm{A}}$ and ten $\mathrm{L}_{\mathrm{IV}-\mathrm{A}}$ animals were intravenously inoculated with $3 \times 10^{7}$ bacteria/0.2ml each. Total antibody titers during primary immune response were determined through the microagglutination technique in 96-well U-bottom plates. Buffered saline solution $(0.05 \mathrm{ml}, \mathrm{pH} 7.2)$ added of $0.1 \%$ gelatin, as diluent, was added to the wells. Then, serial dilutions of $0.05 \mathrm{ml}$ serum samples were carried out. Antigen was $0.05 \mathrm{ml}$ of a bacterial suspension inactivated in autoclave for $1 \mathrm{~h}$, according to 0.5 McFarland scale. Antibody titers were expressed as $\log _{2}$ of the reciprocal of the highest agglutination dilution of the sera.

\section{Delayed-Type Hypersensitivity Reaction}

Ten $\mathrm{H}_{\mathrm{IV}-\mathrm{A}}$ and ten $\mathrm{L}_{\mathrm{IV}-\mathrm{A}}$ animals were intravenously injected with $3 \times 10^{7}$ viable bacteria each as initial sensitizing dose. After fourteen days, DTH reaction was triggered by inoculating animals into the paw with $50 \mu \mathrm{l}$ of the same suspension properly inactivated in autoclave for $1 \mathrm{~h}$. The paw swelling was measured 24 and $48 \mathrm{~h}$ after the eliciting of DTH reaction using a pachymeter. Results were expressed in millimeters (mm).

\section{Statistical Analysis}

The statistical program Graph Pad Software (Instat TM) was used. The results obtained were analyzed using the Students $t$ test to detect differences between each 
infected group and its respective control and between lines $\left(\mathrm{H}_{\mathrm{IV}-\mathrm{A}}\right.$ and $\left.\mathrm{L}_{\mathrm{IV}-\mathrm{A}}\right)$ at each period studied. Results were considered significant when $p<0.05$.

Serological titers obtained from $\mathrm{H}_{\mathrm{IV}-\mathrm{A}}$ and $\mathrm{L}_{\mathrm{IV}-\mathrm{A}}$ mice were compared through nonparametric analysis of variance (ANOVA) using the Kruskal-Wallis test for independent samples.

\section{RESULTS}

\section{Recovery of Viable Bacteria}

Recovery of viable bacteria was analyzed in each organ at different post-infection periods (Figures 1 and 2). The number of viable bacteria in the lungs was larger in $\mathrm{H}_{\mathrm{IV}-\mathrm{A}}$ mice at all periods and differences were statistically significant (Figure 1). Viable bacteria were found in the spleen of $\mathrm{H}_{\mathrm{IV}-\mathrm{A}}$ mice only at day 35 and in that of $\mathrm{L}_{\mathrm{IV}-\mathrm{A}}$ mice at days 21 and 35 (Figure 2). Neither of the lines showed viable microorganisms in the liver. At days 7 and 14, there were not viable bacteria in any organ.

\section{Hydrogen Peroxide Production by Peritoneal Macrophages}

Endogenous production of $\mathrm{H}_{2} \mathrm{O}_{2}$ by peritoneal macrophages was not significantly different between control animals; however, significant differences were observed between lines at days 28 and 42 (Figure 3A).

Phorbol myristate acetate (PMA) stimulus led peritoneal macrophages of both $\mathrm{H}_{\mathrm{IV}-\mathrm{A}}$ and $\mathrm{L}_{\mathrm{IV}-\mathrm{A}}$ mice to increase $\mathrm{H}_{2} \mathrm{O}_{2}$ production. Compared with their respective controls, $\mathrm{H}_{\mathrm{IV}-\mathrm{A}}$ animals produced higher levels of $\mathrm{H}_{2} \mathrm{O}_{2}$ only at day 21 , and $\mathrm{L}_{\mathrm{IV}-\mathrm{A}}$ mice showed decreased $\mathrm{H}_{2} \mathrm{O}_{2}$ production at day 21 and increased production at days 35 and 42 (Figure 3B).

\section{Hydrogen Peroxide Production by Splenic Macrophages}

Control $\mathrm{H}_{I V-A}$ animals had higher endogenous production of $\mathrm{H}_{2} \mathrm{O}_{2}$ by splenic macrophages than control LIV-A mice (Figure 4A). Again, with PMA stimulus, control $\mathrm{H}_{\mathrm{IV}-\mathrm{A}}$ animals produced higher levels of $\mathrm{H}_{2} \mathrm{O}_{2}$ than control $\mathrm{L}_{\mathrm{IV}-\mathrm{A}}$ mice.

Interline differences were significant only at days 21, 28 and 42 after infection (Figure 4B). 


\section{Hydrogen Peroxide Production by Pulmonary Macrophages}

Endogenous production of $\mathrm{H}_{2} \mathrm{O}_{2}$ by pulmonary macrophages was higher in $\mathrm{H}_{\mathrm{IV} \text {-A }}$ than in $\mathrm{L}_{\mathrm{IV}-\mathrm{A}}$ animals. However, production was inhibited in both lines $\left(\mathrm{H}_{\mathrm{IV}-\mathrm{A}}-\right.$ days 28 and 42; LIV-A - days 21, 28 and 42), compared with their respective controls.

Differences between infected lines were significant only at day 21 (Figure 5A). PMA stimulus induced more $\mathrm{H}_{2} \mathrm{O}_{2}$ release in control $\mathrm{L}_{I V-A}$ than in control $\mathrm{H}_{I V-A}$ animals (Figure 5B).

\section{Nitric Oxide Production by Peritoneal Macrophages}

Endogenous production of NO by peritoneal macrophages increased in infected animals compared with their controls. Between control animals, $\mathrm{H}_{\mathrm{IV}-\mathrm{A}}$ mice had higher production of NO than LIV-A mice. Interline differences were observed at days 21 and 35 (Figure 6).

\section{Nitric Oxide Production by Splenic Macrophages}

Control $\mathrm{L}_{\mathrm{IV}-\mathrm{A}}$ animals showed higher endogenous production of $\mathrm{NO}$ than control $\mathrm{H}_{\mathrm{IV}-\mathrm{A}}$ mice. Production was detected only at days 28 and 42, when infected LIV-A animals showed higher $\mathrm{NO}$ levels than infected $\mathrm{H}_{\mathrm{IV}-\mathrm{A}}$ mice. This difference was statistically significant only at day 42 (Figure 7).

\section{Nitric Oxide Production by Pulmonary Macrophages}

Endogenous production of $\mathrm{NO}$ was higher in control $\mathrm{L}_{\mathrm{IV}-\mathrm{A}}$ than in control $\mathrm{H}_{\mathrm{IV}-\mathrm{A}}$ animals. During infection, production was inhibited in both lines compared with their respective controls, and an increase was detected only at day 42 . Interline differences were observed at days 21 and 42 after infection (Figure 8).

\section{TNF- $\alpha$ Production}

Control $\mathrm{L}_{\mathrm{IV}-\mathrm{A}}$ animals produced higher TNF- $\alpha$ levels than control $\mathrm{H}_{\mathrm{IV}-\mathrm{A}}$ mice. Infected LIV-A mice showed increased TNF- $\alpha$ production at days 7,14 , and 28 and infected $\mathrm{H}_{\mathrm{IV}-\mathrm{A}}$ mice, at days 21, 35 and 42 (Figure 9). 


\section{Total Antibody Production}

At the beginning of infection (days 7, 14, and 21), LIV-A mice had antibody titers significantly higher than $\mathrm{H}_{\mathrm{IV}-\mathrm{A}}$ animals. Immune response by $\mathrm{L}_{\mathrm{IV}-\mathrm{A}}$ animals decreased after this period (day 28), being similar to that of $\mathrm{H}_{\mathrm{IV}-\mathrm{A}}$ animals.

Multispecific effect, frequently observed in these lines, did not occur in response to M. bovis (Figure 10).

\section{Delayed-Type Hypersensitivity Reaction}

Infected $\mathrm{H}_{\mathrm{IV}-\mathrm{A}}$ and $\mathrm{L}_{\mathrm{IV}-\mathrm{A}}$ animals showed increased paw swelling compared with their respective controls. $\mathrm{H}_{\mathrm{IV}-\mathrm{A}}$ mice showed more intense DTH reaction than $\mathrm{L}_{\mathrm{IV}-\mathrm{A}}$ mice 24 and $48 \mathrm{~h}$ after the eliciting of reaction, showing better activation of $\mathrm{T}$ cells in vivo (Figure 11). 


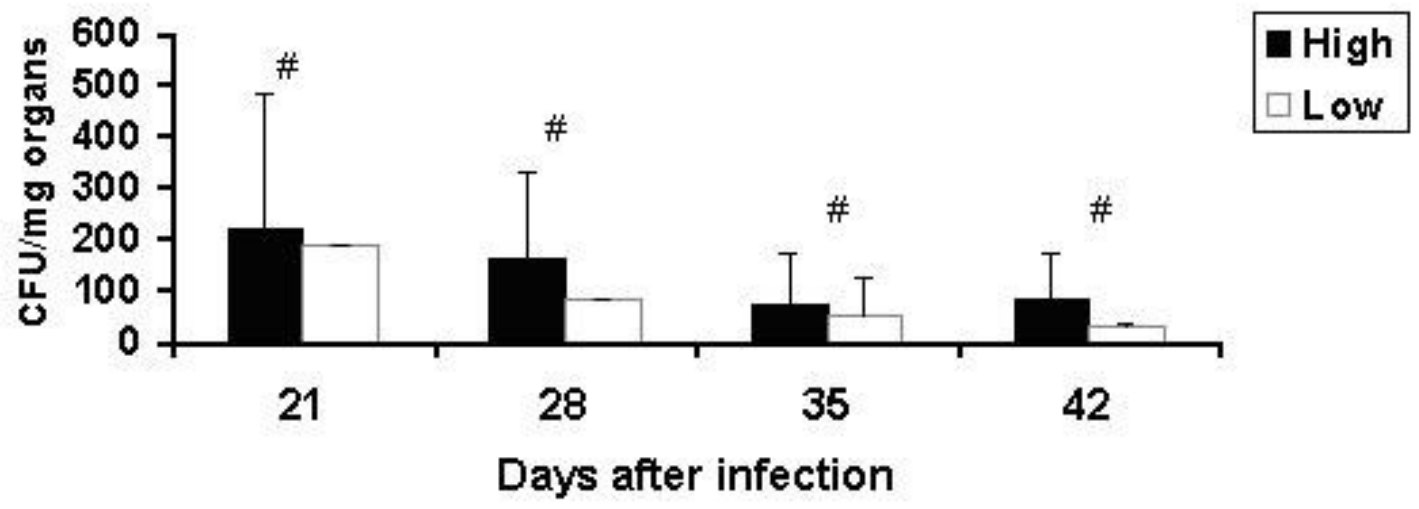

Figure 1. Recovery of viable bacteria (CFU/mg organs) from pulmonary fragments of High and Low antibody producer (Selection IV-A) mice infected with Mycobacterium bovis-AN ${ }_{5}$.

\#: interline difference

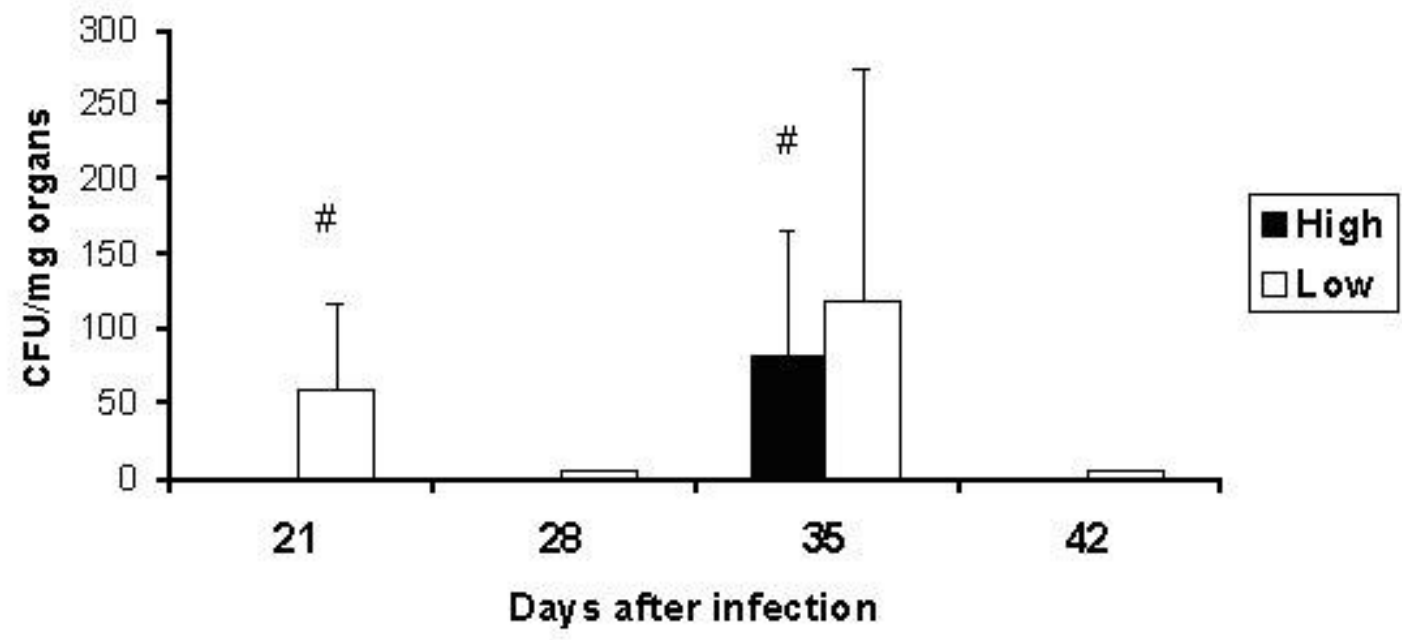

Figure 2. Recovery of viable bacteria (CFU/mg organs) from splenic fragments of High and Low antibody producer (Selection IV-A) mice infected with Mycobacterium bovis- $\mathrm{AN}_{5}$.

\#: interline difference 


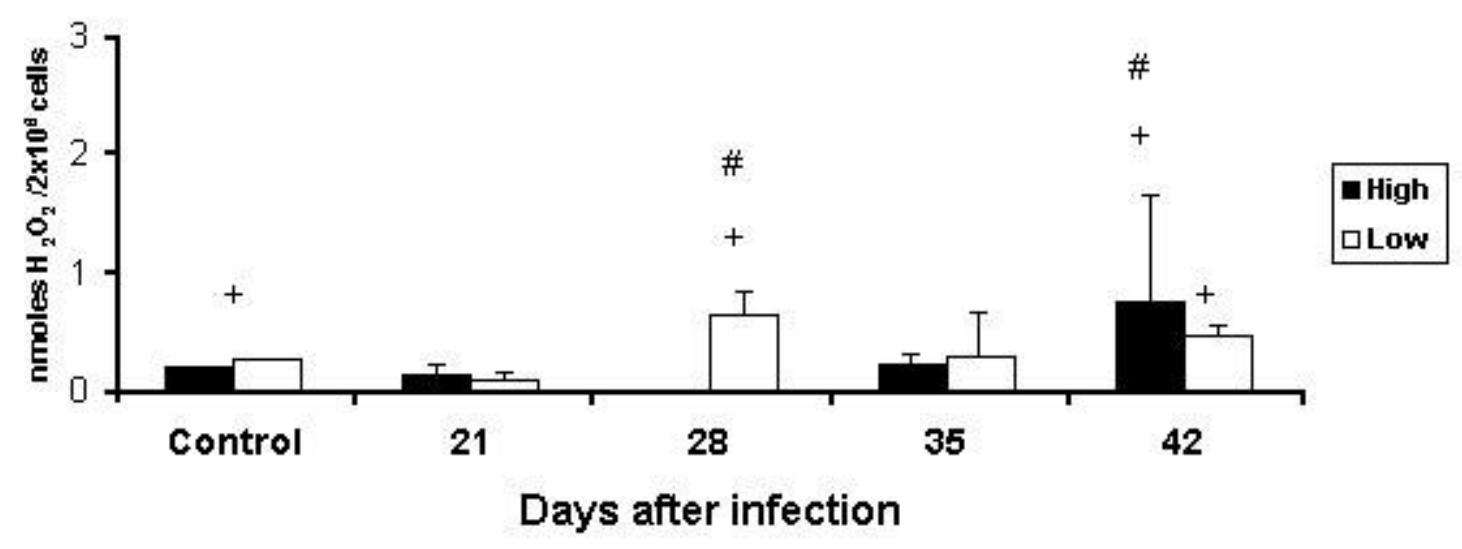

A

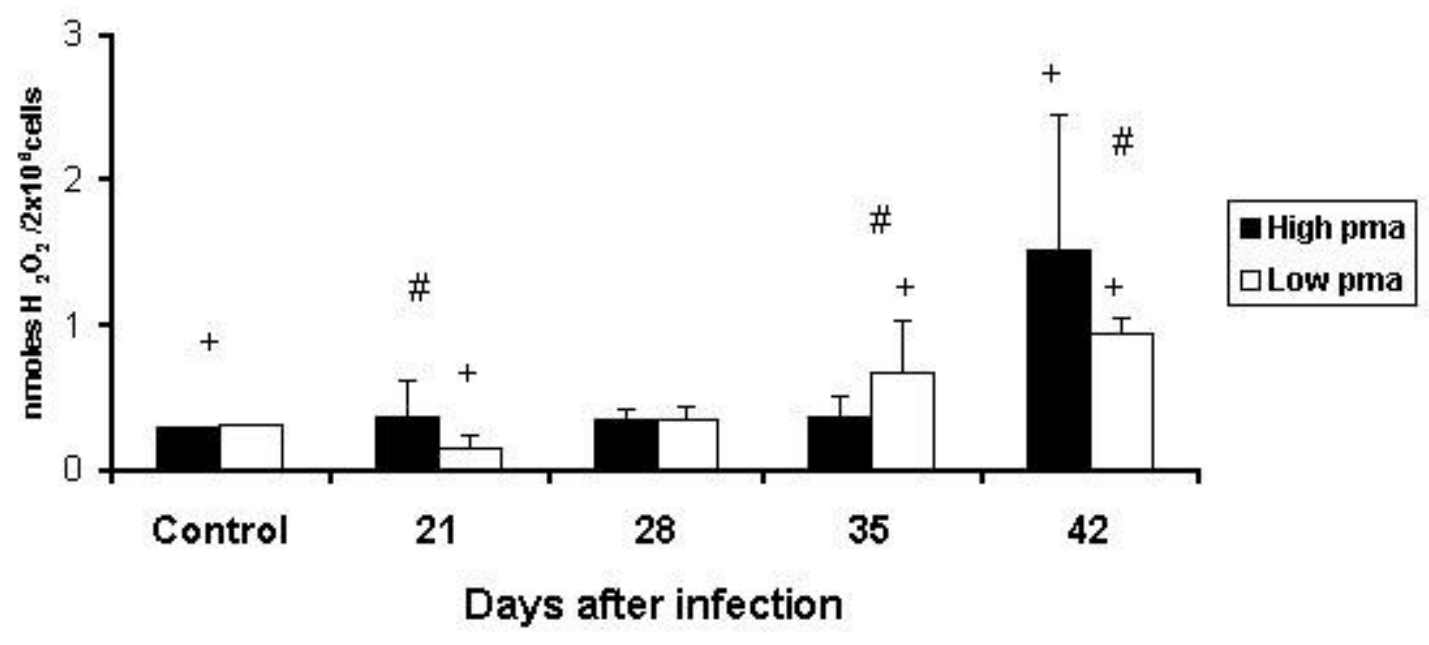

B

Figure 3. Production of $\mathrm{H}_{2} \mathrm{O}_{2}$ (nmoles $\mathrm{H}_{2} \mathrm{O}_{2} / 2 \times 10^{6}$ cells) by peritoneal macrophages of High and Low antibody producer (Selection IV-A) mice infected with Mycobacterium bovis- $\mathrm{AN}_{5}$ at different periods, compared with their respective controls. (A) Endogenous production of $\mathrm{H}_{2} \mathrm{O}_{2}$ by macrophages of infected High and Low mice. (B) Endogenous production of $\mathrm{H}_{2} \mathrm{O}_{2}$ by macrophages of infected High and Low mice subjected to additional phorbol myristate acetate (pma) stimulus.

\#: interline difference

+: difference between infected animals and their respective controls 

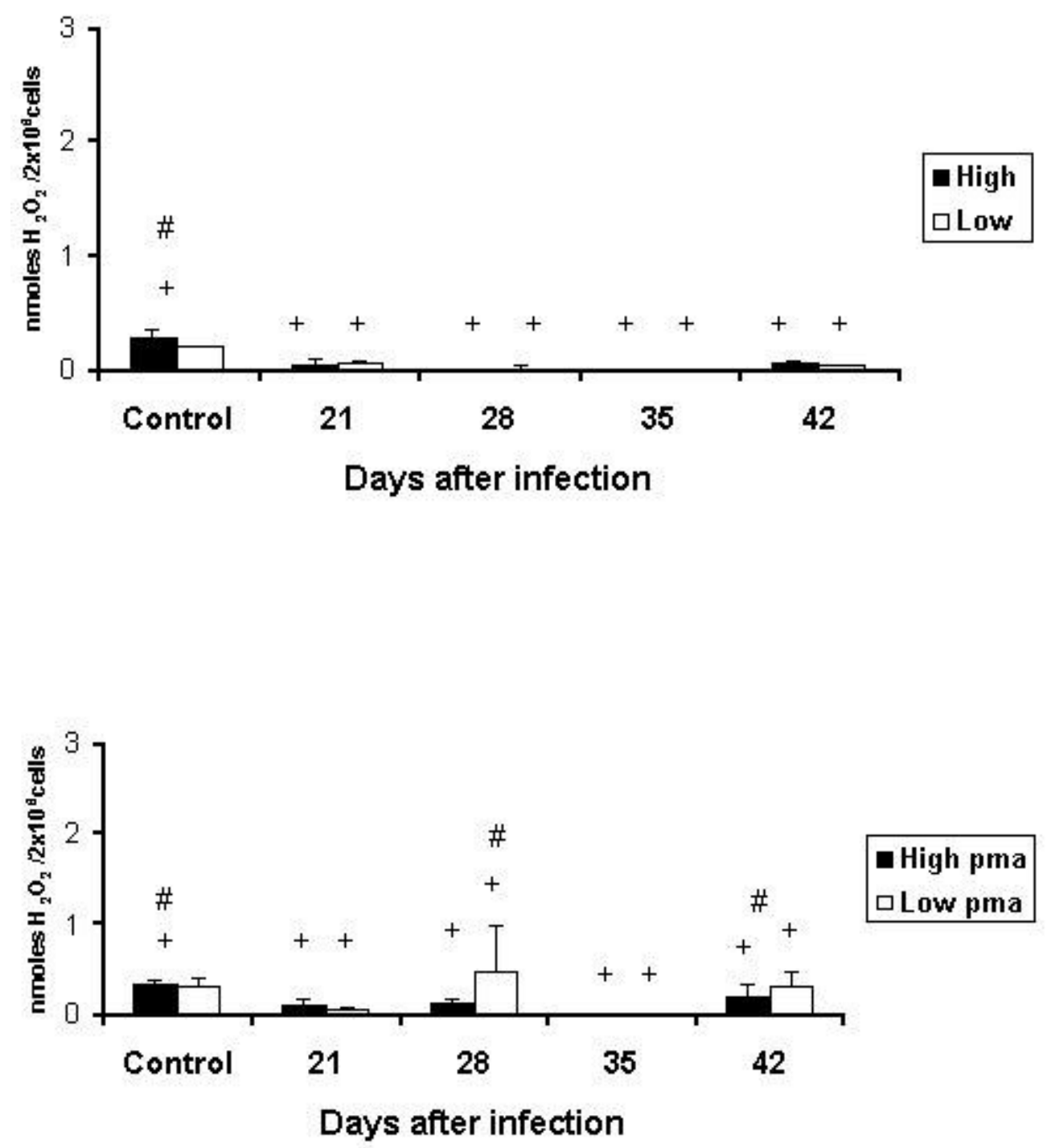

B

Figure 4. Production of $\mathrm{H}_{2} \mathrm{O}_{2}$ (nmoles $\mathrm{H}_{2} \mathrm{O}_{2} / 2 \times 10^{6}$ cells) by splenic macrophages of High and Low antibody producer (Selection IV-A) mice infected with Mycobacterium bovis- $\mathrm{AN}_{5}$ at different periods, compared with their respective controls. (A) Endogenous production of $\mathrm{H}_{2} \mathrm{O}_{2}$ by macrophages of infected High and Low mice. (B) Endogenous production of $\mathrm{H}_{2} \mathrm{O}_{2}$ by macrophages of infected High and Low mice subjected to additional phorbol myristate acetate (pma) stimulus.

\#: interline difference

+ : difference between infected animals and their respective controls 

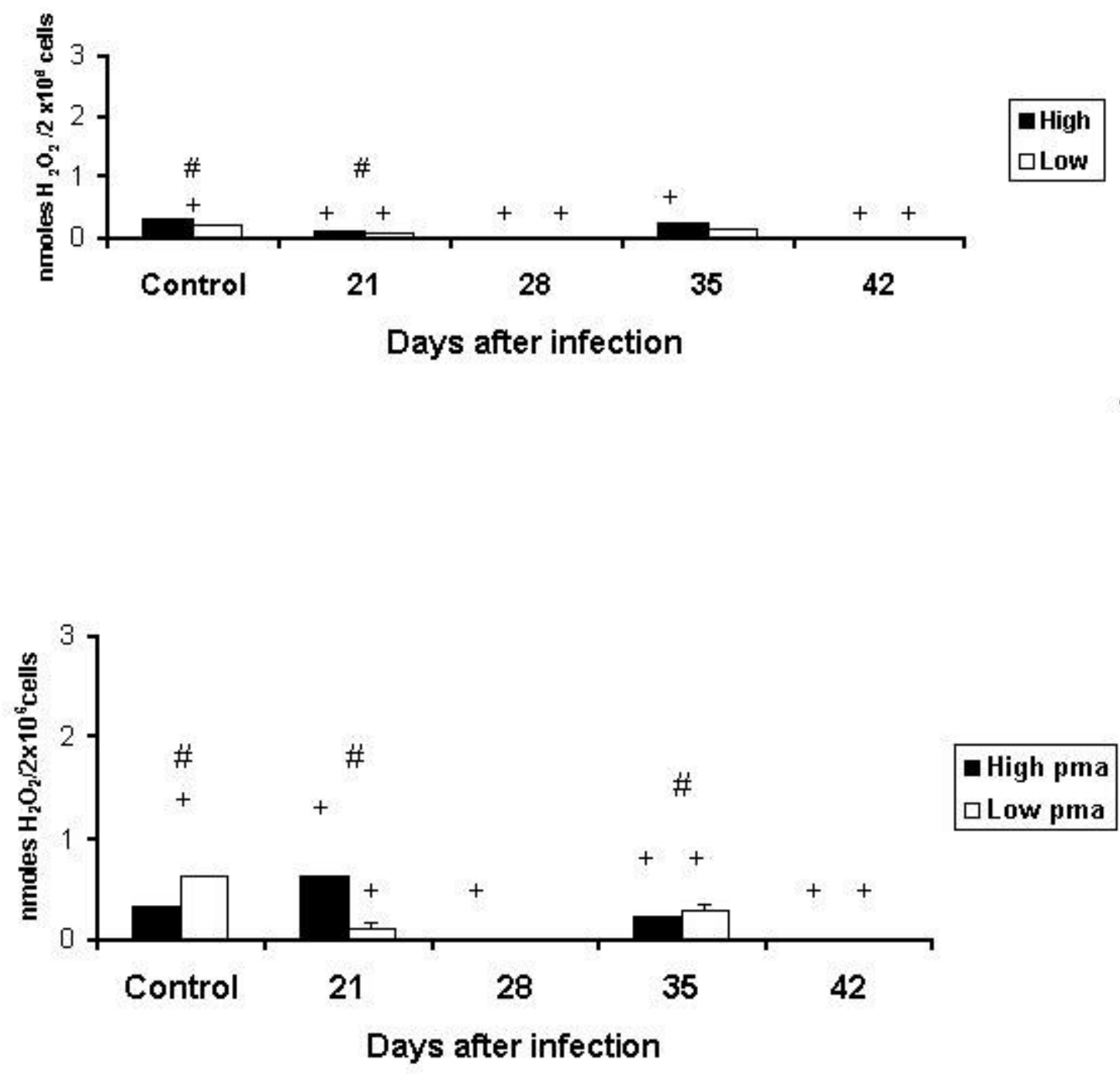

B

Figure 5. Production of $\mathrm{H}_{2} \mathrm{O}_{2}$ (nmoles $\mathrm{H}_{2} \mathrm{O}_{2} / 2 \times 10^{6}$ cells) by pulmonary macrophages of High and Low antibody producer (Selection IV-A) mice infected with Mycobacterium bovis- $\mathrm{AN}_{5}$ at different periods, compared with their respective controls. (A) Endogenous production of $\mathrm{H}_{2} \mathrm{O}_{2}$ by macrophages of infected High and Low mice. (B) Endogenous production of $\mathrm{H}_{2} \mathrm{O}_{2}$ by macrophages of infected High and Low mice subjected to additional phorbol myristate acetate (pma) stimulus.

\#: interline difference

+: difference between infected animals and their respective controls. 


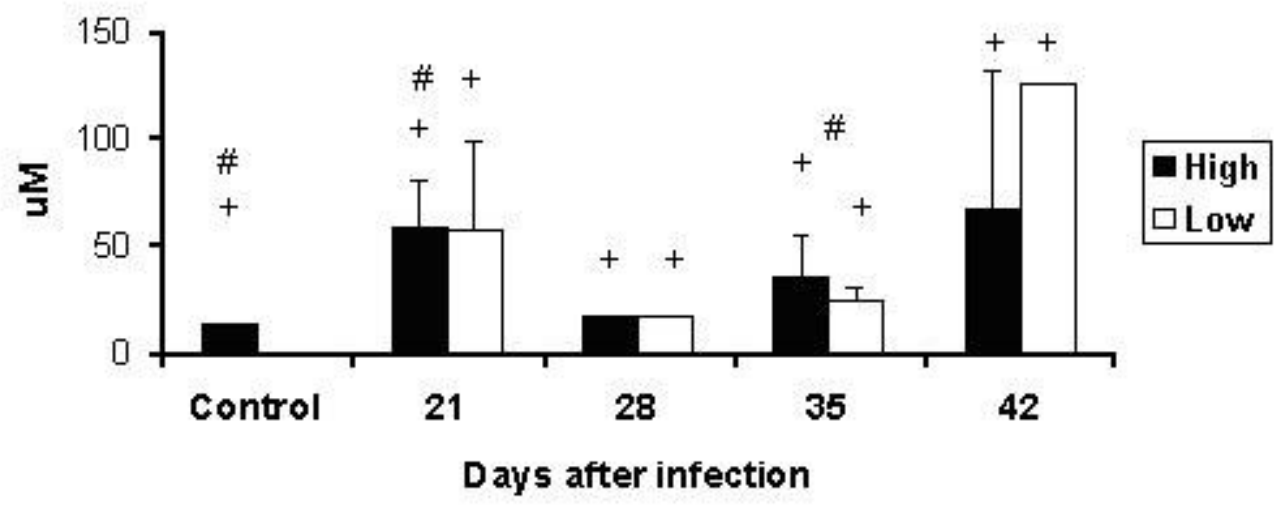

Figure 6. Production of $\mathrm{NO}(\mu \mathrm{M})$ in supernatants from culture of peritoneal macrophages of High and Low antibody producer (Selection IV-A) mice infected with Mycobacterium bovis- $\mathrm{AN}_{5}$ at different periods, compared with their respective controls.

\#: interline difference

+ : difference between infected animals and their respective controls

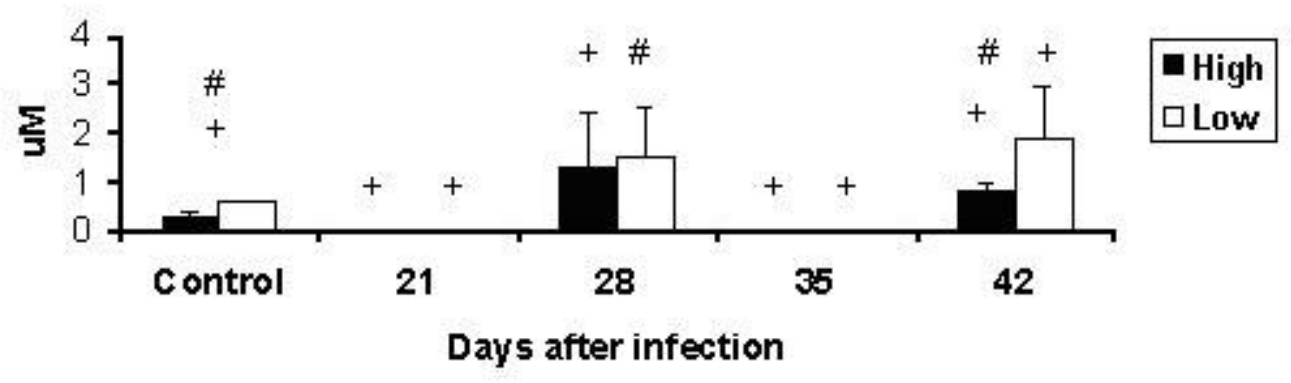

Figure 7. Production of $\mathrm{NO}(\mu \mathrm{M})$ in supernatants from culture of splenic macrophages of High and Low antibody producer (Selection IV-A) mice infected with Mycobacterium bovis- $\mathrm{AN}_{5}$ at different periods, compared with their respective controls.

\#: interline difference

+: difference between infected animals and their respective controls 


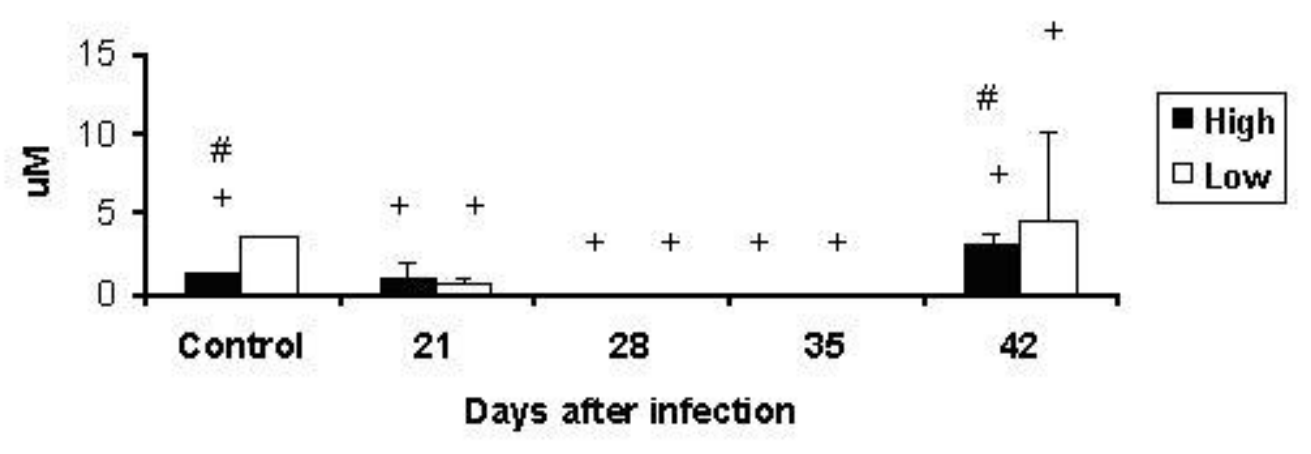

Figure 8. Production of $\mathrm{NO}(\mu \mathrm{M})$ in supernatants from culture of pulmonary macrophages of High and Low antibody producer (Selection IV-A) mice infected with Mycobacterium bovis- $\mathrm{AN}_{5}$ at different periods, compared with their respective controls.

\#: interline difference

+ : difference between infected animals and their respective controls

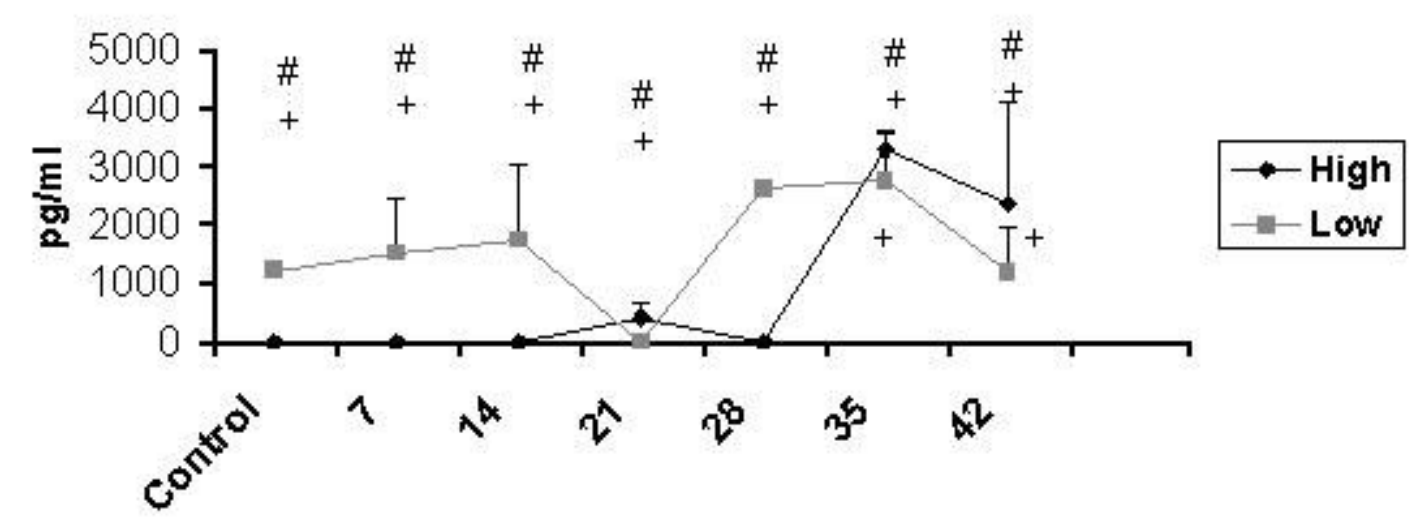

\section{Days after infection}

Figure 9. Concentration of TNF- $\alpha(\mathrm{pg} / \mathrm{ml})$ in sera from High and Low antibody producer (Selection IV-A) mice infected with Mycobacterium bovis- $\mathrm{AN}_{5}$ at different periods, compared with their respective controls.

\#: interline difference

+ : difference between infected animals and their respective controls 


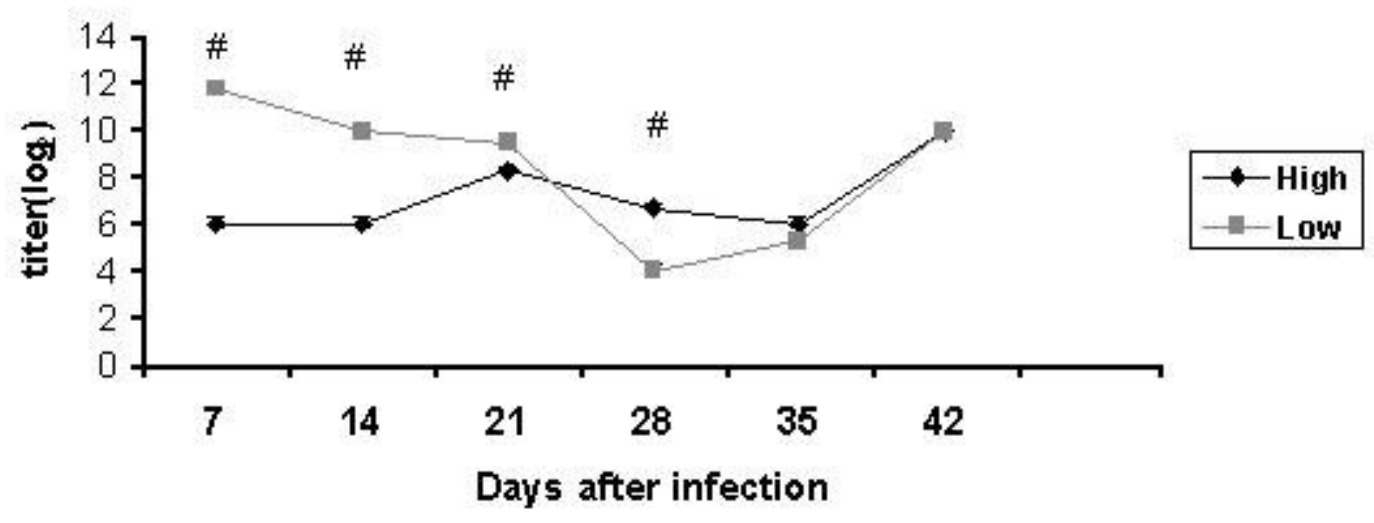

Figure 10. Total anti-Mycobacterium bovis-AN $N_{5}$ antibody titers $\left(\log _{2}\right)$ in sera of High and Low antibody producer (Selection IV-A) mice at different periods after experimental infection. Dosage was performed by direct microagglutination and results were expressed as $\log _{2}$ of the mean $+/$ - standard deviation.

\#: interline differences

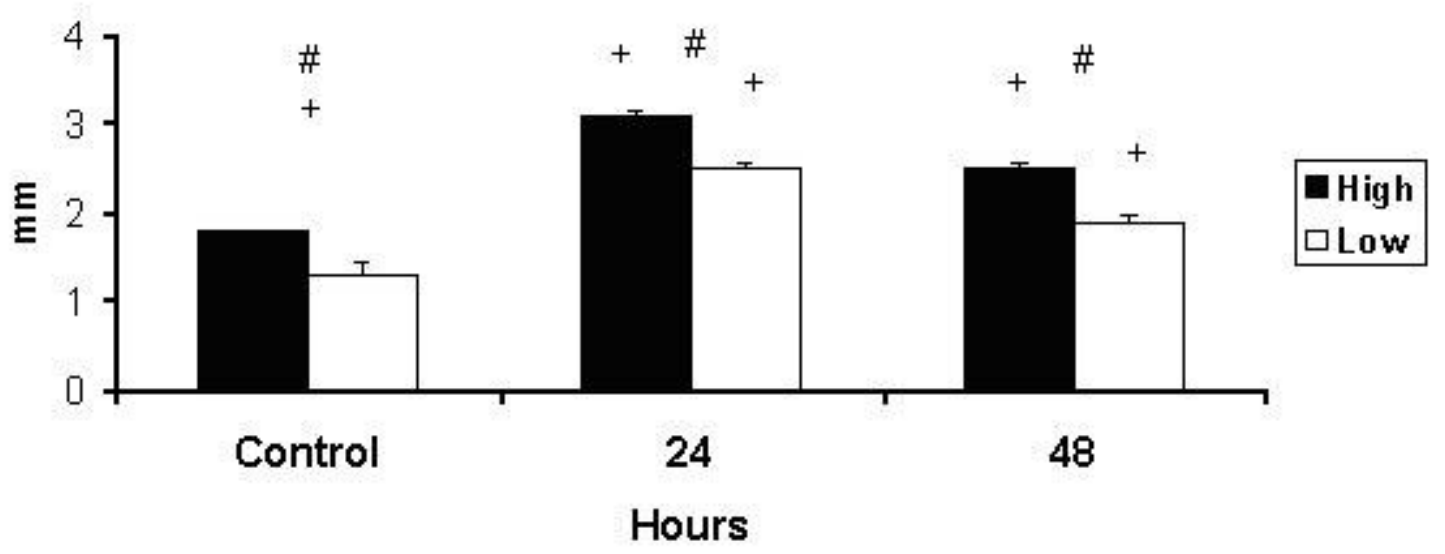

Figure 11. Delayed-type hypersensitivity reaction ( $\mathrm{mm}$ paw swelling) triggered by using inactivated inoculum on the 14th day after sensitization of High and Low antibody producer (Selection IV-A) mice with a suspension of $3 \times 10^{7}$ live Mycobacterium bovis-AN $\mathrm{N}_{5}$. Paw swelling was measured using a pachymeter and results were expressed as mean $+/$ - standard deviation.

\#: interline difference

+ : difference between infected animals and their respective controls 


\section{DISCUSSION}

Genetic control of sensitivity and resistance to infection has been vastly studied lately. Different resistance to intracellular pathogens observed in inbred mouse strains is controlled by one or a few genes, and their expression is not related to the specific immune response (26).

In contrast to inbred strains, mice selected for high or low antibody production show extreme phenotypes, which makes them useful to evaluate the role of the response in infection resistance.

$\mathrm{H}$ mice are more resistant than $\mathrm{L}$ mice against infections in which antibodies play a highly protective role; however, the selective process induced in Selections I and IVA decreased macrophagic activity (17). Several studies have demonstrated that the selective breeding modifies macrophage function in an opposite direction to that of antibody production for Selections I and IV-A (17).

Macrophages of $\mathrm{L}$ mice presented high catabolism of the immunogens with consequent deficiency in their antigen presentation function leading to low antibody production. These animals, however, have shown higher resistance to intracellular pathogens than $\mathrm{H}$ mice, whose macrophages are less catabolic, leading to high antibody production and greater susceptibility to pathogens $(1,4,6,7,13,17,27)$. Lagrange et al. (19) indicated that $\mathrm{H}$ mice, Selection I, were more resistant to virulent M. tuberculosis than $L$ mice and were effectively protected after BCG vaccination. In the present work, a larger number of viable bacteria were found in the lungs of $\mathrm{H}$ mice compared with $L$ mice at all the post-infection periods analyzed; whereas in the spleen, $\mathrm{H}$ mice showed better infection control at every period.

Such results corroborated those previously found in the studied organs, except for higher bacterial recovery in the lungs of $\mathrm{H}$ mice.

It was not possible to establish a positive correlation between $\mathrm{H}_{2} \mathrm{O}_{2}$ production and bacterial recovery because the former was inhibited in the spleen and lungs.

Darrah et al. (11), using knockout mice to evaluate reactive oxygen and nitrogen intermediates production during Rhodococcus equi infection, showed that mice deficient in both macrophage activation routes were susceptible to infection, and neither superoxide nor NO alone could eliminate the agent.

The present results indicate that the increased NO production may be responsible for the small number of bacteria recovered in the spleen of $\mathrm{H}_{\mathrm{IV}-\mathrm{A}}$ mice; however, the same correlation was not observed in the lungs. As NO production in the lungs 
increased in LIV-A animals at the end of infection, this metabolite might also be involved in intramacrophage events that determine the parasite death in this line.

TNF- $\alpha$ production, analyzed together with bacterial recovery, showed that this cytokine was important to control infection in $\mathrm{L}_{\mathrm{IV}-\mathrm{A}}$ lungs and, at the end of infection, the higher production of TNF- $\alpha$ in $\mathrm{H}_{\mathrm{IV}-\mathrm{A}}$ mice helped to decrease the bacteria multiplication in this organ and to eliminate it in the spleen.

Hydrogen peroxide $\left(\mathrm{H}_{2} \mathrm{O}_{2}\right)$, differently from $\mathrm{NO}$ and TNF- $\alpha$, was not an important metabolite to control infection in this experimental model.

Total antibody production against the pathogen studied was also analyzed in order to verify whether the multispecific effect observed in these lines remains the same.

Mycobacterium bovis infection did not follow the resistance and sensitivity patterns usually observed in the lines studied nor the multispecific effect.

Antibody titers from $L_{I V-A}$ mice were significantly higher than those of $\mathrm{H}_{\mathrm{IV}-\mathrm{A}}$ mice until day 21 , but during the following periods, they became similar in both lines.

This result helps to understand the genetic factors responsible for resistance and sensitivity in these lines.

Antibody production against $M$. bovis was compared with the intensity of DTH reaction, which showed to be an important mechanism against intracellular pathogens. Although in some cases it may damage tissues, DTH reaction is involved in the defense against many microorganisms and surface antigens, which are rapidly destroyed by lytic enzymes released by macrophages accumulated in the reaction site.

Delayed-type hypersensitivity reaction is mediated by $\mathrm{T}$ lymphocytes but its induction and manifestation are restricted to products of the MHC. The DTH test is used to evaluate in vivo cellular immune responses, mainly those mediated by Th1 cells. In the present study, reaction was triggered after the 14th day of sensitization, which indicates the presence of cells producing Th1 cytokines to control infection.

We observed that $\mathrm{H}_{\mathrm{IV}-\mathrm{A}}$ mice showed more intense DTH reaction than LIV-A mice, which differs from other studies using the same lines and in which $\mathrm{H}_{\mathrm{IV}-\mathrm{A}}$ animals produced more antibodies against other antigens and had less intense DTH reaction than LIV-A animals.

More and less intense cellular responses in $\mathrm{H}_{\mathrm{IV}-\mathrm{A}}$ mice can be justified by the work of Oliveira et al. (23), which demonstrated that the capability of these lines to produce 
antibodies against antigens not related to those of the Selection is independent of their capability to trigger DTH reactions more or less intense. Humoral and cellular responses to the same antigens present polygenic control and are subject to independent quantitative genetic regulation.

Data presented here differ from those of other works on intracellular parasite infection in the same lines.

Better control of infection was observed in the lungs of $L_{I V-A}$ mice and in the spleen of HIV-A mice.

From the results obtained, we can infer that NO production and the cytokines released by Th1 cells, indirectly evaluated by DTH reaction, played an important role in the protection against M. bovis.

The fact that those lines represent extreme phenotypes found in heterogeneous natural population justify the results obtained, which varied according to the organ and the metabolite analyzed, indicating that different mechanisms interfere in the advanced phase of $M$. bovis infection in heterogeneous natural populations.

\section{REFERENCES}

1 ADORINI L., DORIA G. Defective antigen presentation by macrophages from mice genetically selected for low antibody response. Eur. J. Immunol., 1981, 11, 984-9.

2 BATES JH. Transmission and pathogenesis of tuberculosis. Clin. Chest. Med., 1980, 1, 167-74.

3 BEER J. Enfermedades infecciosas de los animales domésticos. Zaragoza: Acribia, 1981, 2, 347-51.

4 BIOZZI G., MOUTON D., STIFFEL C., BOUTHILLIER Y., DECREUSEFOND C. Selection articielle pour la production d'anticorps chez la souris. Ann. Inst. Pasteur, 1968, 115, 960-5.

5 BLOOD DC., RADOSTITIS OM., GAY CC. Veterinary Medicine. 8.ed. London: Bailliere Tindal, 1994. p.1763.

6 CABRERA WH., SIQUEIRA M., TAKAHASHI NSH., RIBEIRO OG., ARAÚJO LM., MOUNTON D., IBAÑEZ OM. Specific and non-specific T-cell activation in high and low antibody-producing mice (Selection IV-A). Scand. J. Immunol., 1995, 41, 239-97. 7 CANNAT A., BOUSQUET C., SERRE A. Response of high and low antibody producers to Brucella. Ann. Immunol. 1978, 129C, 669-83. 
8 CASTELO A. Avanços na imunopatogênese da infecção pelo HIV. Rev. Assoc. Med. Bras., 1993, 39, 91-193.

9 COLLIN CH. The bovine tubercle bacillus. Br. J. Biomed Sci., 2000, 57, 234-40.

10 CORREAA WM., CORRÊA CNM. Enfermidades Infecciosas dos Mamíferos Domésticos. Rio de Janeiro: MEDSI, 1992. p.843.

11 DARRAH PA., HONDALUS MK., CHEN Q., ISCHIROPOULOS H., MOSSER DM. Cooperation between reactive oxygen and nitrogen intermediates in killing of Rhodococcus equi by activated macrophages. Infect. Immunol., 2000, 68, 3587-93.

12 FIUZA DE MELO FA., AFIUNDE JB. Transmissão e imunopatogenia da tuberculose. J. Pneumol., 1993, 19, 19-24.

13 GENNARI M., BOUTHILLIER Y., IBAÑEZ OM., FERREIRA VCA., MEVEL JC., REIS MH., PIATTI RM., RIBEIRO OG., BIOZZI G. Effect of silica on the genetic regulation of antibody responsiveness. Ann. Inst. Pasteur Immunol., 1987, 138, 35970.

14 GONTIJO FP. Mecanismos imunitários na tuberculose. J. Pneumol., 1978, 22, 28-30.

15 GRANGE JM. The mycobacteria. In: PARKER MT., DVERDEN BL. Topley \& Wilson's principles of bacteriology, virology and immunity. 8.ed. Philadelphia: B.C. Decker, 1990, 2, p.709.

16 GRIESS JM. Bermerkungen zuder Abhandlung der $\mathrm{H} \mathrm{H}$ : we selyund Benedict “Uberlinige Azoverbindungen”. Ber. Deustch. Chem. Ges., 1979, 112, 426-8.

17 IBAÑEZ OM., MOUTON D., OLIVEIRA SL., RIBEIRO FILHO OG., PIATTI RM., SANT'ANNA OA., MASSA S., BIOZZI G., SIQUEIRA M. Polygenic control of quantitative antibody responsiveness: restrictions of the multispecific effect related to the selection antigen. Immunogenetics, 1988, 28, 6-12.

18 JONES TC., HUNT RD. Veterinary Pathology. 15.ed. Philadelphia: Lea Febiger, 1983. p.1792.

19 LAGRANGE PH., HURTREL B., THICKSTUN PM. Immunological behavior after mycobacterial infection in selected lines of mice with high or low antibody responses. Infect. Immunol., 1979, 25, 39-47.

20 MARIANO M. The experimental granuloma. A hypotesis to explain the persistence of the lesion. Rev. Inst. Med. Trop. São Paulo, 1995, 37, 161-76.

21 MOULDING T. Pathogenesis, pathophysiology and immunology. In: SCHLOSSBERG D. Tuberculosis. 2.ed. New York: Springer-Verlag, 1988. p.13-22. 
22 NEILL D. Bovine tuberculosis: pathogenesis of Mycobacterium bovis infection in cattle. Vet. Microbiol., 1994, 40, 41-52.

23 OLIVEIRA SL., IBAÑEZ OM., MOUTON D., SANT'ANNA OA., SIQUEIRA M., BIOZZI G. Independent polygenic regulation of quantitative antibody responsiveness and expression of delayed-type hypersensitivity (DHT). Exp. Clin. Immunogenet., 1985, 2, 223-33.

24 PICK A., KEISARI A. A simple colorimetric method for the measurement of hydrogen peroxide produced by cells in culture. J. Immunol. Methods, 1980, 38, 16172.

25 PICK A., MISEL A. Rapid microassays for the measurement of superoxide and hydrogen peroxide production by macrophages in culture using an automatic enzyme immunoassay reader. J. Immunol., 1981, 46, 2111-26.

26 PLANT J., GLYNN AA. Natural resistance to Salmonella infection delayed hypersensitivity and Ir genes in different strains of mice. Nature, 1974, 248, 345-47.

27 SANT'ANNA OA., MASSA S., MOUNTON D., BOUTHILLIER Y., MEVEL JC., IBAÑEZ OM., VASSAO R., FRANCO M., BELLINATTI R., SIQUEIRA M., BIOZZI G. Salmonella typhimurium infection in high and low antibody responder mice: inverse correlation between antibody responsiveness and resistance to infection. FEMS Microbiol. Immunol., 1989, 47, 465-471.

28 THOEN CO., STEELE JH. Mycobacterium bovis infection in animals and humans. Ames: lowa State University Press, 1995. p.355. 